\title{
Cuban Prophylactic and Therapeutic Vaccines for Controlling Hepatitis B
}

\author{
Eduardo Pentón-Arias MD PhD and Julio C. Aguilar-Rubido PhD
}

\begin{abstract}
Hepatitis B causes liver failure, cirrhosis and cancer. It has an estimated global prevalence of $6 \%$, and 700,000 to 1 million persons die every year of hepatitis B-related causes. In 1989, hepatitis B incidence in Cuba was 14.9 per 100,000 population. To control infection, the Genetic Engineering and Biotechnology Center and the Ministry of Public Health, both in Havana, collaborated on a joint project that first produced natural interferon and recombinant interferon alpha-2b, and later a polyethylene glycolconjugated interferon. As part of the Cuban biotechnology development strategy, the project produced a vaccine against hepatitis B in 1985. At that time, hepatitis $B$ vaccines available elsewhere in the world were costly and inaccessible to Cubans due to the US economic and trade embargo. The Heberbiovac HB preventive vaccine was approved by the Cuban regulatory authority and added to the Cuban newborn vaccination program in 1992 after phase 1-3 clinical trials demonstrated its safety and immunogenicity. From 2001 to 2003, PAHO/WHO qualified and requalified the vaccine four times. When associated with other antigens or molecules, Heberbiovac HB provides a common platform of virus-like particles that can be used in different ways, such as in the pentavalent vaccine containing Bordetella pertussis and Haemophilus influenzae type $\mathrm{b}$ antigens and tetanus and diptheria toxoids.
\end{abstract}

\section{INTRODUCTION}

This paper discusses the Cuban preventive recombinant vaccine for hepatitis $B(\mathrm{HB})$, Heberbiovac $\mathrm{HB}$, which eliminated acute hepatitis $B(A H B)$ from among the nation's health problems. We also discuss a new version, which contains two antigens (rHB$\mathrm{sAg} / \mathrm{rHBcAg}$ ). This version is the precursor to a therapeutic vaccine, HeberNasvac, now supported by four published clinical trials completed in Cuba and Bangladesh.[1-4]

The hepatitis B virus (HBV) causes acute and chronic hepatitis, as well as liver failure, cirrhosis and cancer. Global HB prevalence is estimated at $6 \%$. Every year, more than 4 million persons are infected, and 700,000 to 1 million die. There are reportedly $>350$ million HBV carriers worldwide, of whom approximately $25 \%$ are expected to die of chronic liver disease, cirrhosis or primary hepatocellular carcinoma. In its 2017 Global Hepatitis Report, WHO set a goal to eradicate hepatitis B and C by 2030.[5]

In 1989, HB incidence in Cuba was 14.9 per 100,000 population, and prevalence of chronic hepatitis was $1 \%-5 \%$, according to research on infection detection. Chronically infected patients become reservoirs for virus spread, and it is estimated that at

\section{IMPORTANCE}

This article summarizes 30 years of work by Cuba's Genetic Engineering and Biotechnology Center (CIGB) in controlling hepatitis $B$, the impact of its recombinant preventive vaccine and promising results for a related therapeutic vaccine.
Thanks to this vaccine, annual incidence of acute hepatitis in Cuba has dropped from more than 2000 cases to fewer than 100, and no infections in children aged 0-15 years have been reported since 2007. It is now used in more than 30 countries, providing protective, long-lasting antibody levels with no reports of serious adverse events.

Yet, hepatitis B cannot be eliminated until there are no chronic patients. The comprehensive hepatitis $B$ control project therefore included development of a therapeutic vaccine based on Heberbiovac HB. Using its platform, researchers designed an innovative version of the vaccine that was the precursor of a therapeutic nasal/subcutaneous vaccine for chronic hepatitis $B$, HeberNasvac. This precursor vaccine, which combines Heberbiovac $\mathrm{HB}$ with a recombinant antigen from the virus nucleocapsid ( $\mathrm{rHBcAg})$, was patented and licensed in 2015 by the Cuban regulatory authority. This article provides an overview of the progress-to-date on the development of this therapeutic vaccine, including clinical trials (some completed and others ongoing) to determine safety, efficacy and therapeutic benefits.

KEYWORDS Hepatitis B, vaccines, recombinant DNA, clinical trials, Cuba

least $10 \%$ of new infections become chronic.[6] In the 1980s, $\mathrm{HB}$ vaccines were costly (US\$239 per dose),[7] and the only one was manufactured in the United States, thus off limits to Cuban patients due to the US embargo on Cuba. Thus, as part of its domestic biotechnology development strategy, in 1985, Cuba conducted clinical trials to evaluate the safety, immunogenicity and efficacy of its own prophylactic vaccine (PV) which was then licensed and included in the Cuban vaccination program.[7]

Using prophylactic vaccination, Cuba has reduced HB morbidity and mortality by more than $95 \%$ since $2003,[8]$ but control and elimination cannot be achieved until there are no more patients with chronic $\mathrm{HB}(\mathrm{CHB})$. Cuba has therefore designed and produced a therapeutic vaccine (TV), HeberNasvac, for CHB.

The scientific community has received limited reports on the results of Cuba's development and use of preventive recombinant vaccines for $\mathrm{HB}$, especially on the impact of preventing infection through universal prophylactic vaccination of newborns. This information is important for countries with limited resources because the immunogen used in the prophylactic vaccine, the HBV surface antigen obtained using recombinant DNA technology ( $\mathrm{rHBsAg}$ ), is autochthonous. The PV's rHBsAg is also a component of the TV, which gives the TV the safety and effectiveness demonstrated in prophylactic vaccination over the last 28 years in Cuba and more than 30 countries, with no reports of serious adverse events following immunization (AEFI).[9]

Any biopharmaceutical to be used in the Cuban health system must prove that it can solve or ameliorate a major health problem, and its development and production must be financially self-sustaining.[10] It must also meet the needs of the domestic market 
and create exportable surplus to support continued research and development, as well as the health system, a "closed loop."

Preventive strategies, such as vaccines for $\mathrm{HB}$ and therapies to cure or improve $\mathrm{CHB}$, aim at disease eradication, but immunotherapies such as interferon (IFN), monoclonal antibodies and therapeutic vaccines have received special attention because they link different generations of biotech products. While the Cuban $\mathrm{PV}$ has been shown effective in decreasing HB incidence and mortality, like other countries, Cuba has not been able to reduce prevalence of chronic infection due to poor results from conventional treatments. Therefore, as part of its HB control project and biotechnology development strategy, Cuba decided to develop a TV that would stimulate the immune system to eliminate the virus in $\mathrm{CHB}$ patients.

Our main purpose is not to describe clinical trials of the recombinant PV and TV before their approval, but rather the principles, properties and development of these vaccines. This brief survey of TV clinical trials may also indicate how these vaccines perform in different scenarios, since the TV contains the PV's main component. The PV Heberbiovac HB was licensed 30 years ago and has been used in Cuba and abroad, but what is most impressive is its impact during decades of use in Cuba and elsewhere. The results show that it has controlled and eliminated HBV in Cuban children aged $0-15$, with no major adverse effects and only mild transient effects.[7]

\section{DISCUSSION}

Characteristics and composition of hepatitis $B$ vaccines The Cuban PV and TV for hepatitis B were designed and produced at the Genetic Engineering and Biotechnology Center (CIGB). The Cuban recombinant PV for hepatitis $B$ was licensed as Heberbiovac HB in Cuba in 1990,[11] and by PAHO/WHO in 2003.[7] Each $1 \mathrm{~mL}$ dose of PV for intramuscular administration contains $20 \mu \mathrm{g}$ of the hepatitis B surface antigen " $s$ " produced using recombinant DNA technology ( $\mathrm{rHBsAg}$ ) in $\mathrm{Al}^{3+}$ hydroxide, sodium chloride $(\mathrm{NaCl})$, sodium phosphate dibasic anhydrous or sodium phosphate monobasic dihydrate, and $0.05 \mathrm{mg}$ of thiomersal.[11]

Heberbiovac HB differs from similar vaccines on the global market in three main ways:

1) The recombinant antigen is obtained in a strain of Picchia pastoris yeast transformed by genomic DNA insertion that codes rHBsAg expression, while other vaccines are usually derived from plasmid constructions expressed in Saccharomyces cerevisiae.

2) The process, which involves original chromatographic purification using adsorption and desorption in diatomaceous earth, and industrial columns with immunoaffinity with a suitable, specific and selective monoclonal antibody developed at CIGB, preserves the molecular integrity of the rHBsAg.[12,13]

3) As a result of this process, rHBsAg is obtained as virus-like particles (VLPs) that form aggregates. Within these, a wide variety of epitopes are protected from proteolysis and form highimmunogenicity clusters that preserve antigen diversity, thus favoring a multispecific immune response.

Heberbiovac HB provides a common platform of VLPs with different use options, such as the pentavalent vaccine, included in the
Cuban immunization program after licensing in 2006,[14] which includes antigens for HBV, Bordetella pertussis, and Haemophilus influenzae type b, as well as tetanus and diphtheria toxoids. But the newest example is the HeberNasvac nasal/subcutaneous therapeutic $\mathrm{HBC}$ vaccine, which integrates Heberbiovac $\mathrm{HB}$ with the recombinant HBV nucleocapsid antigen (rHBcAg).

The TV formulation licensed as HeberNasvac [15] contains two recombinant $\mathrm{HBV}$ antigens, and is a mixture of equal parts of rHBsAg produced in $P$. pastoris with recombinant $\mathrm{HBV}$ nucleocapsid antigen ( $\mathrm{rHBcAg}$ ) produced in Escherichia coli. Each $1 \mathrm{~mL}$ dose for intranasal (IN) or subcutaneous (SC) administration contains $100 \mathrm{mg} \mathrm{rHBsAg}+100 \mathrm{mg} \mathrm{rHBcAg}$, suspended in a solution of disodium hydrogen phosphate, disodium phosphate dihydrate, ethylene-diamine-tetra-acetic acid (EDTA) disodium salt, $\mathrm{NaCl}$ and water for injection, without adjuvant.[15] Like Heberbiovac $\mathrm{HB}$, it can provide a common immune-potentiating platform for other antigens.[16,17]

Heberbiovac $\mathrm{HB}$ prophylactic vaccine $\mathrm{CIGB}$ and the Ministry of Public Health (MINSAP) developed an HBV control program for hospitals and community polyclinics to test and administer natural, recombinant and polyethylene glycol-conjugated IFN (PEGIFN), as well as the Heberbiovac HB vaccine.

Phase 1, 2 and 3 clinical trials with a $20 \mu \mathrm{g} / \mathrm{mL}$ dose of Heberbiovac $\mathrm{HB}$ in adults, children and newborns demonstrated its safety, immunogenicity and protective efficacy. The national regulatory authority, the Center for State Control of Medicines and Medical Devices (CECMED), supervised and approved clinical trials performed from 1989 to 1991.[7] This entity licensed the PV[11] and authorized its use in the Cuban immunization program starting in 1992, with a first dose at birth for all newborns and in groups considered at high risk for HBV.[8] Vaccination was organized by MINSAP in collaboration with CIGB, under the supervision of CECMED.

The Cuban vaccine controlled transmission of HBV in vaccinated groups and reduced the annual HBV infection rate in the general population from more than 2000 to fewer than 100 per year (Figure 1). By $2006, \mathrm{HBV}$ incidence had been reduced by $99 \%$ compared to the 1992 rate, before universal vaccination of newborns. Since 2007 , no cases of AHB have been reported in children from birth to

Figure 1: Annual acute Hepatitis B cases in children and the general population, Cuba 1992-2018

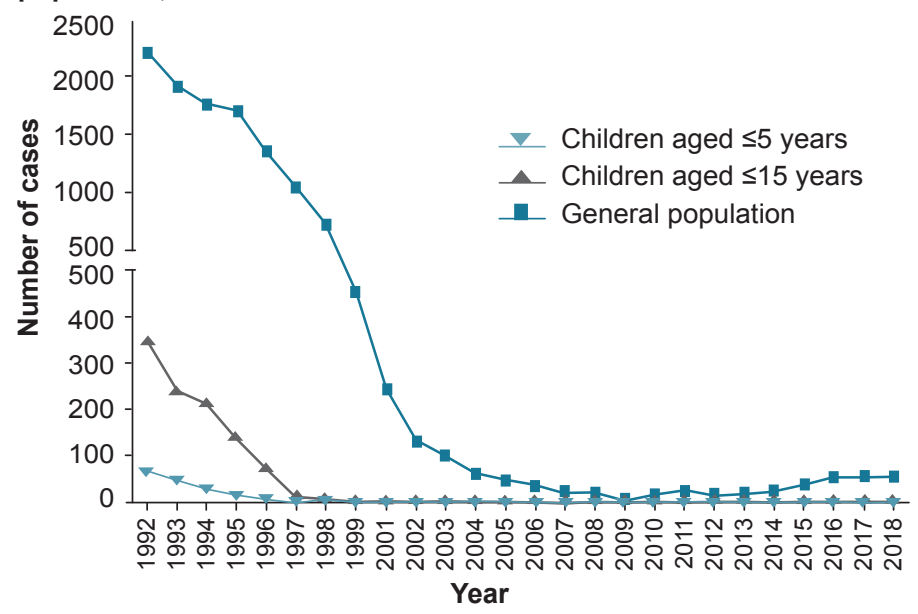


age 15 years.[6] HBV vaccination coverage has been maintained above 98\% since 1994.[6,7] This broad coverage, along with the vaccine's immunogenicity, explains the decreased incidence of $\mathrm{AHB}$ and the absence of new cases in persons aged $<15$ years.

A study published in 2006 reported a perinatal transmission of $3.8 \%$ in children of seropositive mothers $(\mathrm{HBsAg}+)$, proving that the vaccine protects infants born to $\mathrm{HbsAg}+$ mothers, since these children are at high risk of infection.[18]

Since 1992, 80 postmarketing clinical trials of the PV have been conducted in Cuba and other countries in more than 35,000 patients, both adults and children. These trials confirmed its safety, immunogenicity and protective efficacy.[7] Three phase 4 studies conducted in Cuba in infants aged under one year under routine use conditions demonstrated safety similar to that in phase 1-3 clinical trials, and the vaccine's ability to provoke a protective response against HBV in children aged less than five years. This was a long-term response showing antibody titers above $10 \mathrm{IU} / \mathrm{L}$ (protective) 5 years after vaccination in $95.4 \%$ of children.[19]

Additional postmarketing studies involving adult and childhood vaccination were performed in 35 countries on 3 continents. Mild local AEFIs were reported. At 75 days post-vaccination, seroconversion with seroprotection (anti-HB concentrations above $10 \mathrm{IU} / \mathrm{L}$ ) was reported in $92 \%$ of adults and $100 \%$ of children. At two years, the studies confirmed that $100 \%$ of those vaccinated had protective antibody levels.[20] Based on the duration results obtained in different studies and the estimated 3-year half-life of anti-HBs, it was predicted that protective antibody levels would still be present at 15 years post-vaccination.[21]

Despite reduced HB incidence in Cuba and the fact that no AHB cases in children aged $0-15$ years have been reported since 2007, MINSAP continues monitoring children born to $\mathrm{HBsAg+}$ mothers after Heberbiovac HB became part of the national vaccination schedule, because a possibility of hidden infection exists even in the presence of antibodies against the vaccine antigen. A study published in 2016 reported that $2.1 \%$ of children aged 7 months to 5 years, born from 2002 to 2012, had hidden HB infection with positive viral DNA, although they had developed antibodies in response to vaccination.[22] However, later studies found high protection levels in children of seropositive mothers (93.8\%) when they were studied from age 3 to 18 years, and only 1 of 32 children showed hidden infection.[23]

WHO first accepted Heberbiovac HB in 2001 and certified it for compliance with its good manufacturing practices guidelines,[7] thus ensuring that exportable surplus product could be marketed within a closed-loop system.

Immunopathology and immunotherapy in chronic hepatitis B In those who recover from a primary HBV infection (produced by a noncytopathic but immunopathogenic virus) is associated with a strong polyclonal, multispecific and cytotoxic T-cell response against viral nucleocapsid (core) proteins, viral polymerase and the viral envelope antigen.[24,25] However, in patients who develop a persistent necroinflammatory infection, these cell responses are weak or even undetectable. Thus, the predominant immunotherapy trend for $\mathrm{CHB}$ is to promote activation and expansion of a sustained, effective antiviral T-cell immune response. The purpose of the HeberNasvac TV for CHB was to improve the responses elicited by other TV candidates, which failed to resolve the infection.

To eradicate HBV, it must be eliminated in chronic patients, who are disease reservoirs. Various CHB therapies are being explored, which has turned it into a "proving ground" where only IFNs, nucleoside or nucleotide analogues, anti-HB intravenous immunoglobulin, and liver and bone marrow transplants have met US Food and Drug Administration (FDA) requirements and received approval. However, transplants are used only when HBV coexists with other diseases for which transplant is indicated, such as terminal liver failure, leukemias and lymphomas.[26]

Antiviral therapies reported effective in treating $\mathrm{CHB}$ include interferon alpha (IFN-alpha) and PEG-IFN, of which CIGB produces a biosimilar,[27] and nucleoside or nucleotide analogues (NAs). IFN-alpha achieves $10 \%-20 \%$ sustained viral suppression $24-48$ weeks post-treatment, and PEG-IFN shows $30 \%$ effectiveness. $[28,29]$ PEG-IFN has antiviral and immunomodulatory properties, but limited effectiveness because it does not clear infected cells, fails to fully inhibit viral replication since it leaves remaining pockets of virus, and does not effectively reverse weak antiviral T-cell response. NAs are highly effective in controlling HBV and work by inhibiting viral reverse transcriptase,[29] but require lengthy treatment and cause major adverse events (AEs), thereby reducing expected benefits in clinical practice. Although alternative treatments with simple preparations of IFN or PEG-IFN are given for limited periods, they usually cause AEs that sometimes reduce treatment compliance.[30]

Since HB can be eradicated only by preventing new cases and curing chronic patients, in addition to manufacturing the PV and TV, Cuba's strategy for controlling and eradicating HB through prophylactic and therapeutic vaccination was based on developing technologies that allowed it to:

1) Produce and purify polyclonal antibodies against viral antigens. 2) Obtain HBs monoclonal antibodies (McA) to purify rHBsAg and develop analytical and diagnostic methods.

3) Standardize and validate qualitative and quantitative ELISA for viral antigens (HBsAg, anti-HBs, $\mathrm{HBcAg}$, anti-HBc).

4) Develop methods for quantitative determination of viral load $(\mathrm{VL})$ by polymerase chain reaction (qPCR) for HBV DNA. To treat $\mathrm{CHB}$, the natural IFN, recombinant IFN and PEG-IFN therapeutic biomolecules were produced. PEG-IFN prolongs IFN activity by extending its half-life in blood and improving its effectiveness.

Therapeutic vaccine Although no TV in the world has been approved for clinical use, TVs have gained ground among products proposed for treating $\mathrm{CHB}$ in an attempt to eradicate the disease.[21] Cuba has produced the HeberNasvac vaccine candidate, and its safety and efficacy shown in clinical trials reveal its potential to treat patients with chronic disease. This vaccine has been patented[31-33] and was registered in Cuba in 2015.[15]

Its efficacy seems to be related to the presence of trace amounts of nucleic acids from $E$. coli bound to the C-terminal region of the rHBcAg molecule. According to mass spectrometry studies, these nucleic acids make up a nucleoprotein within the VLP that could contribute to the strong immunogenicity of rHBcAg, as well as its adjuvant effect on rHBsAg,[34] which has been proven for other antigens.[16,17] 
This TV's first clinical trials in Cuba involved healthy volunteers and a small number of patients with $\mathrm{CHB}$, and other trials were conducted in Bangladesh (ClinicalTrials.gov NCT 01374308). All were completed and their results published.[1-4] Additional trials are now underway (in Japan and Bangladesh) or in the planning and design stage in other countries. If new trials confirm the results of completed and published studies, HeberNasvac could be recognized as the first effective TV for chronic HBV that contains two antigens originating from the virus. Insertion of $\mathrm{rHBsAg}$ into a TV formulation is also being used as an immune-stimulating carrier and modulator of a synthetic HIV antigen in a TV candidate for treating HIV $[16,17]$ now being used in a clinical trial.

Previous attempts used TVs based solely on rHBsAg that contained potent adjuvants, but failed to control viral replication, although they did show some ability to subvert tolerance to the viral antigen.[25] This effect was attributed to the lack of response against $\mathrm{HBcAg}$, an important $\mathrm{CHB}$ immune marker[35] and to the fact that adoptive transfer of HBcAg-specific T-cells controls HBV and induces anti-HBs seroconversion.[36] This evidence suggested that HBcAg could be used as an immunogen along with rHBsAg to increase the number and variety of epitopes required for an effective antiviral response.[37]

Preclinical experiments in animal models of $\mathrm{CHB}$, including HBV and HBsAg transgenic mice, have demonstrated the immunogenicity of intranasal and subcutaneous HeberNasvac. Pharmacologic, preclinical and toxicologic animal studies have confirmed its safety and efficacy, including experiments with DNA, Dane particles, HBsAg and HBeAg. These studies showed that HBsAg tolerance ended, and strong humoral and cell responses against $\mathrm{HBsAg}$ and $\mathrm{HBcAg}$ began, with a predominantly T helper cell 1 (Th1) immune response. The studies also demonstrated the vaccine's immunogenicity and its ability to induce a response in mucosal and systemic compartments. [38-43] Acute toxicity, repeat-dose and safety studies using intranasal and subcutaneous inoculation showed no local or systemic toxic or adverse effects, or macro- or microscopic changes in organs. $[44,45]$

HeberNasvac can be given as a preventive vaccine in populations with little or no response to conventional prophylactic vaccines, and to healthy persons at risk for HBV. It has shown greater effectiveness and/or fewer AEFIs compared to other treatments. The standard of care for $\mathrm{CHB}$ includes antiviral treatments that effectively suppress the chronic virus but require lifelong antiviral treatment.[46]

HeberNasvac is the first product with activity against $\mathrm{CHB}$ that contains both surface antigens (HBsAg) and nucleocapsid antigens $(\mathrm{HBcAg})$ in the form of VLPs, that can be administered intravenously and/or subcutaneously. Figure 2 outlines the general schedule for patients with $\mathrm{CHB}$ (HBsAg+ for $\geq 6$ months).

Clinical trials with HeberNasvac in healthy volunteers and CHB patients The phase 1 (two trials), phase $1 / 2$ and phase 3 trials were conducted in Cuba, in the Abel Santamaría Cuadrado Provincial Clinical-Surgical Hospital in Pinar del Río Province, Cuba, and in the Bangabandhu Sheikh Mujib Medical University and Farabi Hospitals in Dhaka, Bangladesh, in strict compliance with Good Clinical Practice guidelines, and following the Declaration of Helsinki[47] with certification by CECMED.
Figure 2: HeberNasvac immunization and followup schedules

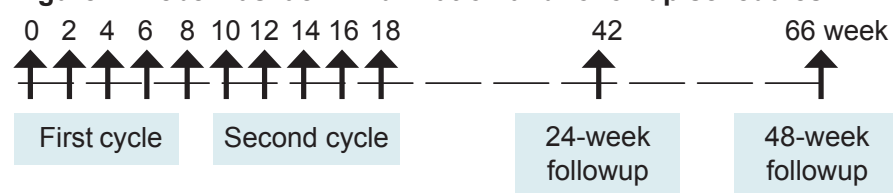

Nasal vaccine: $100 \mu \mathrm{g} \mathrm{HBsAg}$ and $100 \mu \mathrm{g} \mathrm{HBcAg}$

Subcutaneous vaccine: $100 \mu \mathrm{g} \mathrm{HBsAg}$ and $100 \mu \mathrm{g} \mathrm{HBAg}$

After receiving a detailed explanation of the study's risks and benefits, each participant provided written consent. Investigators selected laboratory methods according to principles of maximum possible benefits and minimal possible harm, following good laboratory practices. Each of these clinical trials received approval from the relevant institutional ethics committee and was completed and published.[1-4]

Phase 1 clinical trial in healthy persons A phase 1 (code: IG/VHN/ $\mathrm{HB} / 0201$ ) placebo-controlled, randomized, double-blind trial was conducted in 19 healthy adults ( 9 vaccinated and 10 who received placebo) to evaluate the preliminary safety and immunogenicity of intranasal immunization with HeberNasvac, following a schedule of 5 doses containing $50 \mu \mathrm{g}$ of each antigen per dose $(0.5 \mathrm{~mL})$, at 14-day intervals.[1]

In this trial, HeberNasvac showed a safety profile comparable to that of the saline solution used as placebo (Table 1).

The vaccine showed high safety and minimal reactogenicity. There were no unexpected or serious AEFIs, and no volunteers left the study due to them. Basic hematology and clinical chemistry parameters showed no abnormalities. The AEFIs noted were mild and few; local AEFIs most often seen were sneezing, rhinorrhea, nasal obstruction and laryngeal itching, all occurring in $<35 \%$ of patients. Among systemic AEFIs, most common were headache and general malaise, both in $<10 \%$ of cases.

This clinical trial demonstrated the immunogenicity of HeberNasvac, since $100 \%$ of vaccinated subjects responded to $\mathrm{HBcAg}$ with anti-HBc titers $>1: 10$. A high percentage of subjects generated an anti-HBs protective response (concentrations $\geq 10 \mathrm{IU} / \mathrm{L}$ ), and of these, more than half were good responders (anti-HBs $\geq 100 \mathrm{IU} / \mathrm{L}$ ). The volunteers in the placebo group remained negative for both antibodies throughout the study.

The licensed therapeutic HBV vaccines produce a seroprotective response of up to $20 \%$ after the first dose and $71 \%$ one month after the second dose in healthy young adults.[48,49] These were encouraging results, considering that these were the first humans immunized intranasally with $\mathrm{HBsAg}$, and that the TV was not yet optimized for dose and vaccination schedules. Subsequent studies focused on testing higher concentrations of the antigen by dose and number of inoculations.

Phase 1 clinical trial in $C H B$ patients A phase 1 clinical trial evaluated the safety of an active immunotherapy schedule with HeberNasvac administered intranasally in six patients with $\mathrm{CHB}$ refractory to treatment with recombinant interferon alfa- $2 b$, the standard of antiviral care for $\mathrm{CHB}$ in Cuba. Average patient age 
Table 1: Summary of clinical trials to evaluate HeberNasvac

\begin{tabular}{|c|c|c|c|c|}
\hline & $\begin{array}{c}\text { Phase } 1 \mathrm{CT} \text { in healthy } \\
\text { volunteers[1] }\end{array}$ & $\begin{array}{c}\text { Phase } 2 \mathrm{CT} \text { in } \mathrm{CHB} \\
\text { patients[2] }\end{array}$ & $\begin{array}{c}\text { Phase } 2 / 3 \mathrm{CT} \text { in } \mathrm{CHB} \\
\text { patients [3] }\end{array}$ & $\begin{array}{c}\text { Phase } 3 \mathrm{CT} \text { in } \mathrm{CHB} \\
\text { patients }[4]\end{array}$ \\
\hline Country & Cuba & Cuba & Bangladesh & Bangladesh \\
\hline Design & $\begin{array}{l}\text { Placebo-controlled, } \\
\text { randomized, double-blind trial }\end{array}$ & Open single-arm trial & Open two-arm trial & $\begin{array}{l}\text { Open, randomized, two-arm trial } \\
\text { with control treatment (PEG-IFN) }\end{array}$ \\
\hline Objective & $\begin{array}{l}\text { Preliminary safety and } \\
\text { inmunogenicity }\end{array}$ & $\begin{array}{l}\text { Preliminary safety and } \\
\text { immunogenicity }\end{array}$ & Safety and immunogenicity & $\begin{array}{l}\text { Efficacy, inmunogenicity and } \\
\text { safety }\end{array}$ \\
\hline $\begin{array}{l}\text { General } \\
\text { demographics }\end{array}$ & $\begin{array}{l}\mathrm{N}=19 \text {, healthy volunteers } \\
\text { Healthy young men (18-45 } \\
\text { years) } \\
9 \text { with TV and } 10 \text { with } \\
\text { placebo }\end{array}$ & $\begin{array}{l}\mathrm{N}=6,18-65 \text { years, failed } \\
\text { alfa-2b IFN treatment } \\
3 \mathrm{HBeAg}+ \\
3 \mathrm{HBeAg}-\end{array}$ & $\begin{array}{l}\mathrm{N}=20,19-65 \text { years, no } \\
\text { prior treatment. } \\
13 \mathrm{HBeAg}+ \\
7 \mathrm{HBeAg}-\end{array}$ & $\begin{array}{l}\mathrm{N}=160,18-65 \text { years, }>80 \% \\
\text { without prior treatment } \\
\sim 80 \% \mathrm{HBeAg}- \\
80 \text { with TV and } 80 \text { with PEG-IFN }\end{array}$ \\
\hline $\begin{array}{l}\text { Treatment, schedule, } \\
\text { routes and dose }\end{array}$ & $\begin{array}{l}0,1,2,4,6 \text { weeks } \\
\text { IN }(50 \mu g / A g / \text { dose }) \\
\text { vs placebo, same schedule }\end{array}$ & $\begin{array}{l}0,2,4,6,8,10,12,14,16 \text {, } \\
18 \text { weeks } \\
\text { IN }(100 \mu \mathrm{g} / \mathrm{Ag} / \text { dose })\end{array}$ & $\begin{array}{l}2 \text { cycles } \\
1 \text { st: } 0,2,4,6,8 \text { weeks } \\
\text { IN }(100 \mu g / A g / \text { dose }+100 \\
\mu g \text { HBcAg) } \\
\text { 2nd: } 12,14,16,18,20 \\
\text { weeks } \\
\text { IN }(100 \mu g / A g / \text { dose+100 } \\
\mu g \text { HBcAg) } \\
\text { SC }(100 \mu g / A g / \text { dose })\end{array}$ & $\begin{array}{l}2 \text { cycles } \\
\text { 1st: } 0,2,4,6,8 \text { weeks } \\
\text { IN }(100 \mu \mathrm{g} / \mathrm{Ag} / \text { dose+100 } \mu \mathrm{g} \\
\text { HBcAg) } \\
\text { 2nd: } 12,14,16,18,20 \text { weeks } \\
\text { IN }(100 \mu \mathrm{g} / \mathrm{Ag} / \text { dose+100 } \mu \mathrm{g} \\
\text { HBcAg+100 } \mu \mathrm{g} \text { HBcAg) } \\
\text { SC }(100 \mu \mathrm{g} / \mathrm{Ag} / \text { dose }) \\
\text { vs PEG-IFN } 48 \text { weeks }\end{array}$ \\
\hline $\begin{array}{l}\text { Main results with } \\
\text { focus on safety }\end{array}$ & $\begin{array}{l}\text { Demonstrated safety and } \\
\text { immunogenicity when given } \\
\text { via IN route, } 100 \% \text { anti- } \\
\text { HBcAg response and sero- } \\
\text { protection in } 77.7 \%(7 / 9) \text { of } \\
\text { immunized patients }\end{array}$ & $\begin{array}{l}\text { Demonstrated safety } \\
\text { in CHB patients and } \\
\text { initial evidence of antiviral } \\
\text { response in } 2 \text { of } 3 \text { patients } \\
\text { with HBeAg+. Long-term } \\
\text { followup of viral load } \\
\text { detected virus in } 1 \text { of } 6 \\
\text { subjects in last followup } \\
\text { blood draw. Generalized } \\
\text { normalization of transami- } \\
\text { nases. }\end{array}$ & $\begin{array}{l}\text { Demonstrated safety and } \\
\text { immunogenicity based } \\
\text { on in vitro detection of } \\
\text { proinflammatory cytokines. } \\
\text { Evidence of efficacy, such } \\
\text { as decreased viral load in } \\
\text { most patients; } 50 \% \text { had } \\
\text { undetectable levels at end } \\
\text { of followup. Sustained } \\
\text { antiviral response and } \\
\text { generalized normalization } \\
\text { of transaminases. }\end{array}$ & $\begin{array}{l}\text { Fewer adverse events related } \\
\text { to HeberNasvac compared to } \\
\text { PEG-IFN. } \\
\text { Similar antiviral efficacy during } \\
\text { treatment. Sustained response } \\
\text { of HeberNasvac favored signifi- } \\
\text { cantly superior antiviral effect at } \\
24 \text { and } 48 \text { weeks post-treatment. } \\
\text { Generalized normalization of } \\
\text { transaminases observed. }\end{array}$ \\
\hline
\end{tabular}

CHB: Chronic hepatitis B CT: Clinical trial IN: Intranasal HBeAg: Marker of an actively replicating hepatitis B virus infection PEG-IFN: Polyethylene glycol-conjugated interferon SC: Subcutaneous TV: Therapeutic vaccine

was 43 years, and average time since diagnosis was 13.5 years (Table 1). All were serum HBsAg+ for more than six months and had transaminase levels (ALAT and/or ASAT) above the upper limit of normal, detected at least once within six months prior to trial inclusion.

Subjects received ten $100 \mu \mathrm{g}$ doses of HeberNasvac $(1 \mathrm{~mL})$ intranasally every two weeks (Table 1), using a nasal actuator (VP7D, Valois, France) calibrated to release $125 \mu \mathrm{L}$ of the formula with each plunger depression. The vaccine was safe, showed low reactogenicity, and was well tolerated by all patients. The vaccination did not cause liver, kidney or bone marrow dysfunction. These patients had documented histories of over 12 years with $\mathrm{CHB}$ that had been refractory or not fully responsive to IFN-alpha for 10 years, and had various comorbidities (alcohol consumption and advanced age).

HBsAg became undetectable in 1 of 6 patients, and 2 of 6 seroconverted to anti-HBs, one in week 24 , with no reversion after 5 years of followup (Figure 3). Alanine aminotransferase (ALAT) elevations were transient, and no patients developed cirrhosis during followup, which suggests that ALAT elevations were benign.[2] Results of vibration-controlled transient elastography (FibroScan, Echosens, France) showed slow progression and low fibrosis levels.
The improvement in virologic and serologic variables associated with HBV and mild fibrosis after five years of followup suggest that in addition to the therapeutic benefits of the TV, it may protect the liver. With regard to clinical practice guidelines for HB infection,[46] none of the patients required additional treatment.

HeberNasvac produced no serious AEFIs. There were no deaths, or any onset of chronic disease during followup (52 weeks). Most AEFIs noted were mild and resolved without medical intervention. The most common AEFIs (more than $10 \%$ of total) were: sneezing, general malaise, headache and asthenia. Other local AEFIs were noted, such as nasal secretions, mild localized burning sensation at the inoculation site, and nasal pruritus. After completion of the study, which demonstrated safety and an antiviral effect, SC administration was adopted to complement IN, for improved clinical benefits.[2]

Phase 1/2 clinical trial in previously untreated CHB HeberNasvac was evaluated in a 2009 phase 1/2 clinical trial in 20 treatmentnaïve patients with an average age of 28 years residing in Dhaka, Bangladesh (Table 1). All had HBsAg+ lasting more than 6 months, detectable viral load, ( $\geq 1000$ copies of $\mathrm{HBV} \mathrm{DNA} / \mathrm{mL}$ ), and elevated transaminases within 6 months of inclusion. Patients with $\mathrm{HBeAg}+$ and $\mathrm{HBeAg}$ - were included. 
Figure 3: Copies of HBV DNA and concentration of HBsAg (qHBsAg) in sera of 6 patients 5 years after HeberNasvac administration

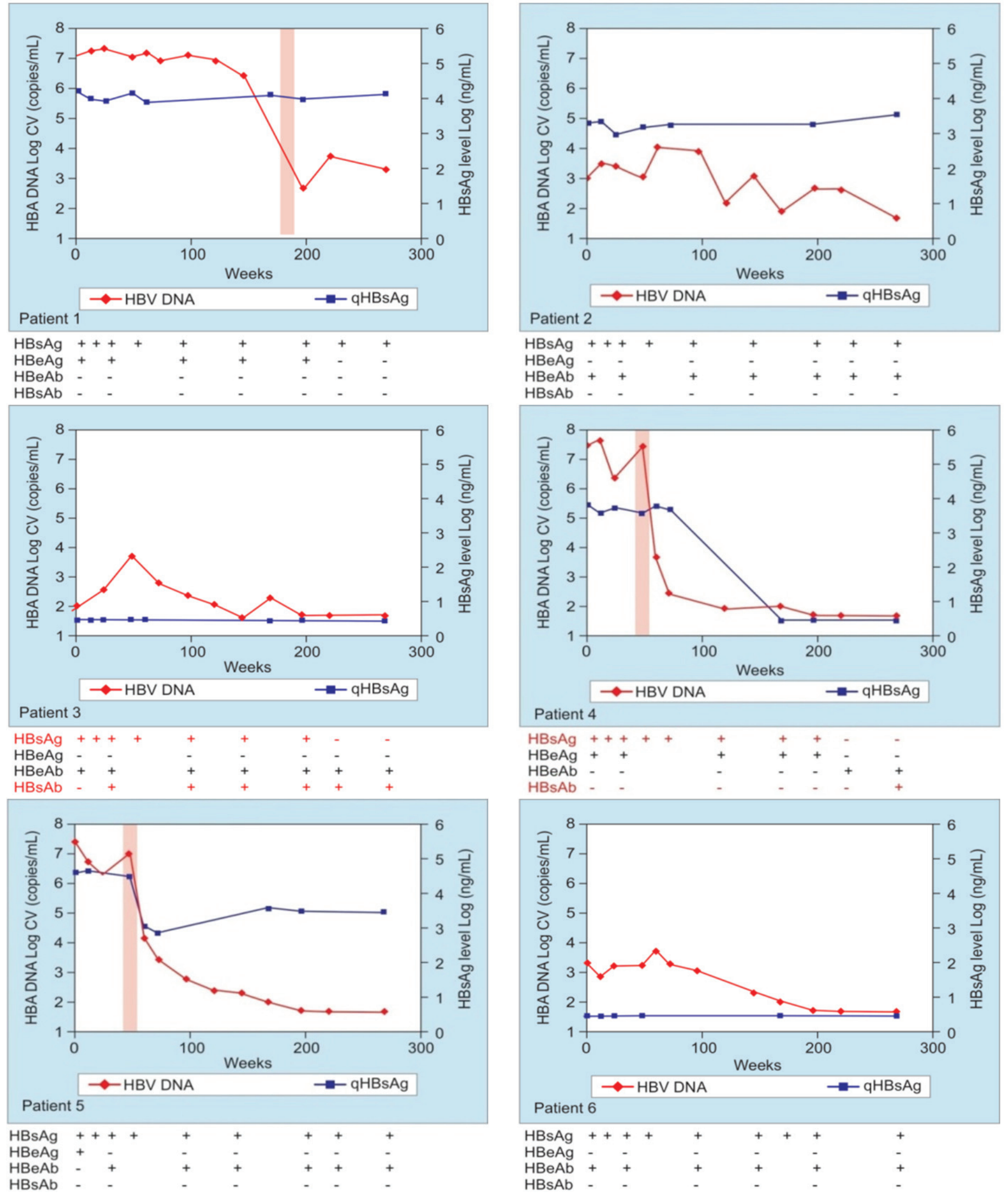

The results of the serological tests are shown below each graph for each patient (patients 1 to 6 ). The time frame of ALAT elevations are represented by a pink shaded bar. Figure taken from ref [2]; with publisher's permission. HBV DNA: Hepatitis B virus DNA 
The TV was given intranasally in the first 5-dose treatment cycle (each $1 \mathrm{~mL}$ dose contained $100 \mu \mathrm{g} \mathrm{HBsAg}+100 \mu \mathrm{g} \mathrm{HBcAg}$ ); in the second cycle, the 5 doses were given intranasally and subcutaneously at the same time. The study measured virologic response using quantitative PCR (250 copies $/ \mathrm{mL}$ detection limit) after 5 and 10 doses. After 48 weeks, a high percentage of patients who were $\mathrm{HBeAg}$ - had eliminated HBV, and ALAT normalized in all patients. Of those who joined the study with $\mathrm{HBeAg}+$, six cleared the virus from circulation, eight seroconverted to anti-HBe (HBeAg became negative and antibodies against it appeared), and ALAT levels became normal for sustained periods.

That viral load reduction was maintained during followup is of interest because in a high percentage of patients treated with current antivirals, the virus reappears once treatment ends. SC and IN administration of HeberNasvac was safe and well tolerated in all subjects. No serious or moderate AEFIs were recorded. All AEFIs noted during the second treatment cycle were associated with SC administration; $100 \%$ of these were mild, including pain at injection site (27.8\%), fever (22.2\%) and general malaise (11.1\%).

Because the vaccine was given both IN and SC in this clinical trial, it provided the first safety and efficacy profiles of the HeberNasvac regimen for both routes. Vaccination with $\mathrm{rHBs} / \mathrm{rHBcAg}$ via both routes induced production of proinflammatory cytokines and activation of antigen-presenting dendritic cells in the peripheral blood of CHB patients and demonstrated the TV's immunomodulatory effect after the first five intranasal doses.[3]

The investigators in this trial recommended that HeberNasvac manufacturers use the regimen in a phase 3 clinical trial to assess effectiveness and offer a more in-depth perspective on its safety and efficacy.

Phase 3 clinical trial in untreated CHB patients This phase 3 trial was conducted in Bangladesh and was approved by the ethics committees of the participating hospitals and the Bangladesh General Office of Medication Administration. It was registered on ClinicalTrials.gov (NCT01374308). This trial used the same schedule and dose as the phase 1/2 trial and compared TV to PEG-IFN treatment (Table 1). General results indicate that over the short and long term, HeberNasvac was safer than PEG-IFN as an immunotherapy agent in $\mathrm{CHB}$ patients. In patients treated with PEG-IFN, AEs were significantly more common, intense, prolonged and associated with the treatment, mostly consisting of fever, weakness, headache and localized pain.[11]

During the trial, investigators detected transient ALAT elevations twice the upper limit of normal in week 12 after 5 nasal vaccinations. This was seen in a higher percentage of patients treated with HeberNasvac than in patients who received PEG-IFN, and occurred regardless of patient HBeAG status, sex, age, or initial viral load. As was seen in the phase 1 trial in $\mathrm{CHB}$ patients, ALAT elevations were transient in the group receiving HeberNasvac. In every case, they occurred in week 12 , and were 5 to 10 times greater than the upper limit of normal.[4] ALAT increases in patients treated with PEG-IFN had a similar range of intensity (up to $300 \mathrm{U} / \mathrm{L}$ ) but occurred in fewer patients and not in week 12.

Increased ALAT levels in nearly all patients receiving HeberNasvac suggests that these were the result of beneficial immune activation to eliminate the virus after five IN doses, and that this route supports HeberNasvac's mechanism of action. Results in a model of HBV transgenic mice showed that the IN (not parenteral) route was associated with a higher proportion of multifunctional T CD4+ cells that migrated to the liver. CD8+ cells were present in lower proportions.[38]

At end of treatment, the antiviral effect was similar in both groups, but HeberNasvac showed better sustained control of HBV DNA during followup. At 24 weeks post-treatment, a higher proportion of HBV DNA ( $<250$ copies $/ \mathrm{mL}$ ) had been cleared in subjects who received HeberNasvac than in those who received PEG-IFN. This was seen as lower levels of viral DNA. Patients treated with HeberNasvac had less progression in their hepatic fibrosis. Compared to patients who received PEG-IFN, HBeAg disappeared in a higher proportion of patients treated with HeberNasvac, and more patients treated with HeberNasvac seroconverted to anti-HBe.

The hypothesis of this trial was tested at 24 weeks post-treatment. Intention-to-treat analysis showed a significantly higher proportion of patients with a viral load $<250$ copies/mL (HBV DNA undetectable) in the group immunized with HeberNasvac. Protocol analysis showed a similar difference. A rebound in viremia, more pronounced in the PEG-IFN group, occurred after treatment, with a significant reduction in the proportion of patients with controlled viral load (<250 copies $/ \mathrm{mL}$ ) at 24 week followup compared to end of treatment.[4]

The results for the Cuban PV and TV discussed here show their impact on prevention of acute hepatitis in different age groups and on treatment of chronic forms of the disease. For the TV, better results will depend on the antigens selected or designed for formulations, adjuvant adsorption strategies, the most useful immunization route and possible receptors, for which appropriate biomarkers must be selected. Other studies are also needed to confirm the relevance of mucosal immunization and its mechanisms of action in the field of therapeutic vaccination.

The marketing registration granted to HeberNasvac in Cuba and the first international collaboration using this TV in Japan and other Asian countries[50,51] are encouraging signs for patients with $\mathrm{CHB}$. To find a permanent cure and eradicate HB, however, we will need strategies that combine TV with conventional therapies and others still being tested, since single treatments have not succeeded thus far in eliminating the virus and curing chronic patients.

\section{CONCLUSIONS}

Acute hepatitis B has ceased to be a health problem in Cuba after universal vaccination of newborns with the Cuban prophylactic vaccine Heberbiovac HB. Because Cuba has systematically administered the vaccine in a broad-ranging national program, it has maintained low annual incidence in the general population, and no cases have been reported in children since 2007. Compared to PEG-IFN, therapeutic vaccination with HeberNasvac via both routes has fewer adverse events, reduces long-term viral load without reversion in a higher proportion of patients, and decreases transaminase and rigidity values. Transient ALAT elevations are associated with immune activation, not development of hepatic fibrosis. HeberNasvac is a safe alternative as monotherapy for short-term treatment of CHB. The HeberNasvac TV is a practical example of biotech product innovation in Cuba. $1 /$ - 


\section{REFERENCES}

1. Betancourt AA, González Delgado CA, Estévez ZC, Martínez JC, Ríos GV, Moreno AureolesRoselló SR, et al. Phase I in healthy adults of a nasal vaccine candidate containing recombinant hepatitis B surface and core antigens. Int J Infect Dis. 2007 Sep;11(5):394-401

2. Fernández $G$, Sánchez $A L$, Jerez $E$, Anillo LE, Freyre F, AguiarJA, et al. Five-year follow-up of chronic hepatitis $B$ patients immunized by nasal route with the therapeutic vaccine HeberNasvac. Euroasian J Hepato-Gastroenterol. 2018 Jul -Dec;8(2):133-9.

3. Al-Mahtab M, Akbar SMF, Aguilar JC, Uddin MH, Khan MSI, Rahman S. Therapeutic potential of a combined hepatitis B virus surface and core antigen vaccine in patients with chronic hepatitis $B$. Hepatol Int. 2013 Oct:7(4):981-9.

4. Al Mahtab M, Akbar SMF, Aguilar JC, Guillén G Pentón E, Tuero A, et al. Treatment of chronic hepatitis $B$ naïve patients with a therapeutic vaccine containing $\mathrm{HBs}$ and $\mathrm{HBc}$ antigens (a randomized, open and treatment controlled phase III). PLoS One. 2018 Aug 22;13(8):e0201236.

5. Global Hepatitis Report 2017 [Internet]. Geneva: World Health Organization; 2017 Apr [cited 2020 Nov 2]. 83 p. Available at: https://www .who.int/hepatitis/publications/global-hepatitis -report2017/en/

6. Torres Vidal RM, Galindo Sardiña MA, Valcárcel Sánchez M. Enfermedades prevenibles por vacunas. Morbilidad y mortalidad. In: Rojas Ochoa F, editor. Vacunas. Cuba.1959-2008 [Internet]. Havana: ECIMED; 2011 [cited 2020 Nov 2]. p. 43. Available at: http://www.bvscuba.sld.cu/libro/ vacunas-cuba-1959-2008/. Spanish.

7. Muzio V, Quiñones Y, Quintana M. Vacuna cubana contra la hepatitis B. Impacto de un producto biotecnológico en la salud pública. In: Rojas Ochoa F. Vacunas. Cuba.1959-2008 [Internet]. Havana: ECIMED; 2011 [cited 2020 Nov 27]. p. 134. Available at: http://www.bvscuba.sld.cu/ libro/vacunas-cuba-1959-2008/. Spanish.

8. Reed G, Galindo MA. Cuba's National Immunization Program. MEDICC Rev. 2007 Oct;9(1):5-7.

9. López Ambrón L, Egües Torres LI, Pérez Carreras A, Galindo Santana BM, Galindo Sardiña MA, Resik Aguirre S, et al. Experiencia cubana en inmunización, 1962-2016. Rev Panam Salud Pública. 2018 Apr 24;42:e34. DOI: 10.26633/ RPSP.2018.34. Spanish.

10. Cuba's biotech boom. Nature. 2009 Jan 8;457(7226):130. DOI: https://doi.org/10.1038/45 $7130 \mathrm{a}$

11. Center for State Control of Medicines and Medical Devices (CECMED) [Internet]. Havana: Ministry of Public Health (CU); c2020. Registro. RCP. HEBERBIOVAC HB® . (VACUNAANTIHEPATITIS B RECOMBINANTE); 2017 [cited 2020 Nov 27]. 5 p. Available at: https://www.cecmed.cu/re gistro/rcp/heberpentar-l-vacuna-pentavalente-liqui da-difteria-tetanos-tos-ferina-hepatitis-b. Spanish.

12. Hardy E, Martínez E, Diago D, Díaz R, González $D$, Herrera L. Large-scale production of recombinant hepatitis $B$ surface antigen from Pichia pastoris. J Biotechnol. 2000 Feb 17;77(2-3):157-67.

13. Agraz A, Quiñones $Y$, Expósito N, Breña F, Madruga J, Pentón E. Adsorption-desorption of recombinant hepatitis $B$ surface antigen ( $r-H B s A g)$ from $P$. pastoris on a diatomaceous earth matrix: Optimization of parameters for purification. Biotechnol Bioeng. 1993 Nov 20;42(10):1238-44.

14. Center for State Control of Medicines and Medical Devices (CECMED) [Internet]. Havana: Ministry of Public Health (CU); c2020. Registro. RCP. Heberpenta ${ }-L$ (Vacuna pentavalente líquida contra la difteria, tétanos, tos ferina, hepatitis B y Haemophilus influenzae tipo b); [cited 2020 Nov 27]. 6 p. Available at: https://www.cecmed.cu/ registro/rcp/heberpentar-l-vacuna-pentavalente -liquida-difteria-tetanos-tos-ferina-hepatitis-b. Spanish.

15. Center for State Control Medicines and Medical Devices (CECMED) [Internet]. Havana: Ministry of Public Health (CU); c2020. Registro. RCP. HeberNasvac $®$ (Vacuna terapéutica recombinante contra la hepatitis B); [cited 2020 Nov 27] 6 p. Available at: https://www.cecmed.cu/registro/ rcp/hebernasvacr-vacuna-terapeutica-recomb inante-hepatitis-b. Spanish.

16. Iglesias E, García D, Carrazana Y, Aguilar JC, Sánchez A, Gorobaya L, et al. Anti-HIV-1 and anti-HBV immune responses in mice after parenteral and nasal co-administration of a multiantigenic formulation. Curr HIV Res. 2008 Sep;6(5):452-60.

17. Iglesias E, Thompson R, Carrazana $Y$, Lobaina Y, García D, Sánchez J, et al. Co-inoculation with hepatitis B surface and core antigen promotes a Th1 immune response to a multiepitopic protein of HIV-1. Immunol Cell Biol. 2006 Apr;84(2):174-83.

18. Bello Corredor M, Díaz González M, Heng Hung Ricardo L, Delgado González G, Montalvo Villalba $\mathrm{MC}$, et al. Marcadores serológicos en lactantes de alto y bajo riesgo de infección por el virus de la hepatitis $B$ inmunizados con una vacuna recombinante cubana. Paediatrica. 2006;8(1):7-14. Spanish.

19. Muzio González V, Cinza Estévez Z, Ortega Tápanes A, Véliz Ríos G, Galindo MA, Delgado $\mathrm{G}$, et al. Estudios postlicenciamiento de la vacuna cubana contra la hepatitis $B$, Heberbiovac HB. Biotecnol Aplic. 2001 Apr;18(2):103-4. Spanish.

20. Ramírez Albajéz V, González Griego A, Alerm González A, Vega García I, Pentón Arias E, González Griego M. Seguridad e inmunogenicidad de la vacuna cubana Heberbiovac HB en poblaciones de América, Europa, Africa y Asia. Rev Cubana Invest Bioméd. 2000 JanApr;19(1):28-33. Spanish.

21. Zumaeta E, González Griego A, Ferrandiz J, Villanueva A, Soto V, Almeida R, et al. Pronóstico de duración de títulos protectores anti-HBs ag en trabajadores de la salud del Perú luego de 6 años de vacunados. Rev Gastroenterol Perú [Internet]. 2001 Oct-Dec [cited 2020 Nov 29];21(4):276-81. Available at: http://www.scielo .org.pe/scielo.php?script=sci_arttext\&pid=S1022 $-51292001000400004 \&$ Ing $=$ es. Spanish.

22. Bello Corredor M, Rodríguez Lay LA, Rodríguez Argueta D, Montalvo Villalba MC, Pedroso Flaquet $\mathrm{P}$, Sariego Frómeta $\mathrm{S}$, et al. Infección oculta por el virus de la hepatitis $B$ en hijos de madres positivas al HBsAg. VacciMonitor. 2016 Jan -Apr;25(1):1-6. Spanish.

23. Rodríguez Lay LA, Bello Corredor M, Montalvo Villalba MC, Chibás Ojeda AG, Sariego Frómeta S, Díaz González M, et al. Hepatitis B virus infection assessed 3 to 18 years after vaccination in Cuban children and adolescents born to HBsAg-positive mothers. Arch Virol. 2017 Aug;162(8):2393-6.

24. Jung MC, Pape GR. Immunology of hepatitis B infection. Lancet Infect Dis. 2002 Jan;2(1):43-50.

25. Michel ML, Deng Q, Mancini-Bourgine M. Therapeutic vaccines and immune-based therapies for the treatment of chronic hepatitis B: perspectives and challenges. J Hepatol. 2011 Jun;54(6):1286 -96 .

26. Verna EC. Updated Hepatitis B guidance: implications for liver transplant patients. Liver Transpl. 2018 Apr;24(4):465-9.

27. Center for State Control Medicines and Medical Devices (CECMED) [Internet]. Havana: Ministry of Public Health (CU); c2020. Registro. RCP. PEG-Heberon ${ }^{\circledR}$ (Interferón alfa $2 b$ hu-rec conjugado a polietilenglicol); [cited 2020 Nov 30]. 8 p.
Available at: https://www.cecmed.cu/registro/rcp/ peg-heberonr-interferon-alfa-2b-hu-rec-conjuga do-polietilenglicol. Spanish

28. Shamliyan TA, MacDonald R, Shaukat A, Taylor BC, Yuan JM, Johnson JR, et al. Antiviral therapy for adults with chronic hepatitis B: a systematic review for a National Institutes of Health Consensus Development Conference. Ann Intern Med. 2009 Jan 20;150(2):111-24.

29. Lin $\mathrm{CL}, \mathrm{Kao} \mathrm{JH}$. Recent advances in the treatment of chronic hepatitis B. Expert Opin Pharmacother. 2011 Sep;12(13):2025-40.

30. Scaglione SJ, Lok ASF. Effectiveness of hepatitis $B$ treatment in clinical practice. Gastroenterology. 2012 May;142(6):1360-8.

31. Aguilar Rubido JC, Palenzuela Gardón DO, Muzio González VL, Guillén Nieto GE, Pentón Arias E, Pichardo Díaz D, et al, inventors; Center for Genetic Engineering and Biotechnology (CIGB), assignee. WO2000032229 A1 Preparations containing virus-like particles as immunopotentiators administered through the mucosa. Cuba patent CU PCT/CU1999/000006. 2008 Jun 6.

32. Aguilar Rubido JC, Pentón Arias E, Tleugabulova D, Sewer Mensies M, Muzio González VL, Guillén Nieto GE, et al, inventors; Center for Genetic Engineering and Biotechnology (CIGB), assignee. WO2002043756 A2 Method for obtaining antigenic aggregates and the use thereof in formulations. Cuba patent CU PCT/ CU2001/000009. 2002 Jun 6

33. Aguilar Rubido JC, Lobaina Mato Y, Iglesias Pérez E, Pentón Arias E, Guillén Nieto GE, Aguiar Santiago JA, et al, inventors; Center for Genetic Engineering and Biotechnology (CIGB), assignee. WO2017167317 A1 Pharmaceutical composition that includes the surface and nucleocapsid antigens of the hepatitis $\mathrm{B}$ virus. Cuba patent $\mathrm{CU}$ PCT/CU2017/050001. 2017 Oct 5.

34. Aguilar JC, Lobaina Y, Muzio V, García D, Pentón E, Iglesias E, et al. Development of a nasal vaccine for chronic hepatitis B infection that uses the ability of hepatitis B core antigen to stimulate a strong Th1 response against hepatitis B surface antigen. Immunol Cell Biol. 2004 Oct;82(5):539-46.

35. Vandepapelière P, Lau GKK, Leroux-Roels G, Horsmans Y, Gane E, Tawandee T, et al. Therapeutic HBV Vaccine Group of Investigators. Therapeutic vaccination of chronic hepatitis $B$ patients with virus suppression by antiviral therapy: a randomized, controlled study of co-administration of $\mathrm{HBsAg/AS02}$ candidate vaccine and lamivudine. Vaccine. 2007 Dec 12;25(51):8585-97.

36. Lau GK, Suri D, Liang R, Rigopoulou El, Thomas MG, Mullerova I, et al. Resolution of chronic hepatitis B and anti-HBs seroconversion in humans by adoptive transfer of immunity to hepatitis B core antigen. Gastroenterology. 2002 Mar;122(3):614-24.

37. Aguilar JC, Lobaina Y. Immunotherapy for chronic hepatitis B using HBsAg-based vaccine formulations: from preventive commercial vaccines to therapeutic approach. Euroasian J Hepatogastroenterol. 2014 Jul-Dec;4(2):92-7.

38. Bourgine M, Crabe S, Lobaina Y, Guillén G, AguiIar JC, Michel ML. Nasal route favors the induction of $\mathrm{CD} 4(+) \mathrm{T}$ cell responses in the liver of HBV-carrier mice immunized with a recombinant hepatitis B surface- and core-based therapeutic vaccine. Antiviral Res. 2018 May;153:23-32.

39. Mancini-Bourgine M, Guillén G, Michel ML, Aguilar JC. Impact of the immunogen nature on the immune response against the major HBV antigens in an HBsAg and HLA-humanized transgenic mouse model. Euroasian J Hepatogastroenterol. 2014 Jan-Jun;4(1):36-44.

40. Bourgine M, Dion S, Godon O, Guillén G, Michel $\mathrm{ML}$, Aguilar JC. Optimization of immune respons- 
es induced by therapeutic vaccination with crossreactive antigens in a humanized hepatitis $B$ surface antigen transgenic mouse model. Virology. 2012 Aug 15;430(1):10-9.

41. Trujillo $H$, Blanco A, García D, Freyre F, Agu iar J, Lobaina $\mathrm{Y}$, et al. Optimization of a therapeutic vaccine candidate by studying routes, immunization schedules and antigen doses in HBsAg-positive transgenic mice. Euroasian $J$ Hepatogastroenterol. 2014 Jul-Dec:4(2):70-8.

42. Akbar SMF, Yoshida O, Chen S, Aguilar JC, Abe $M$, Matsuura $B$, et al. Immune modulator and antiviral potential of dendritic cells pulsed with both hepatitis $B$ surface antigen and core antigen for treating chronic HBV infection. Antivir Ther. 2010;15(6):887-95.

43. Akbar SMF, Chen S, Al-Mahtab M, Abe M, Hiasa $Y$, Onji M. Strong and multi-antigen specific immunity by hepatitis B core antigen ( $\mathrm{HBcAg}$ )based vaccines in a murine model of chronic hepatitis $\mathrm{B}$ : HBcAg is a candidate for a therapeutic vaccine against hepatitis $B$ virus. Antiviral Res 2012 Oct;96(1):59-64.

44. Porras DN, Cosme K, Aldana L, Bacardí D, Merino N, Milá L, et al. Determination and assess ment of the irritant potential of a nasal vaccine candidate, which combines Hepatitis B surface antigen and Hepatitis B core antigen. Biotecnol Aplic. 2004 Jan;21(3):143-7.

45. Lobaina Mato Y, Aguilar Rubido JC, Guillén Nieto $G$. ABX203, a novel therapeutic vaccine for chronic hepatitis B patients. Almanac Clin Med 2016 Sep;44(6):713-8.
46. Terrault NA, Bzowej NH, Chang KM, Hwang JP, Jonas MM, Murad MH, et al. AASLD guidelines for treatment of chronic hepatitis B. Hepatology. 2016 Jan;63(1):261-83.

47. World Medical Association. Declaration of Helsinki: ethical principles for medical research involving human subjects. JAMA [Internet]. 2013 Nov 27 [cited 2018 Jun 13];310(20):2191-4. Available at: https://jamanetwork.com/journals/jama/fullar ticle/10.1001/jama.2013.281053

48. Jilg $W$, Schmidt $M$, Deinhardt $F$. Vaccination against hepatitis $B$ : comparison of three different vaccination schedules. J Infect Dis. 1989 Nov;160(5):766-9.

49. Cassidy WM, Watson B, Ioli VA, Williams K, Bird S, West DJ. A randomized trial of alternative two- and three-dose hepatitis $B$ vaccination regimens in adolescents: antibody responses, safety, and immunological memory. Pediatrics. 2001 Apr;107(4):626-31.

50. Yoshida O, Imai Y, Akbar SMF, Kohara M, Kohara K, Miyazak T, et al. A nasal administrative therapeutic vaccine (NASVAC) with modified treatment strategy reduces and eliminates HBs antigen in HBV infected patients with or without nucleos(t)ide analogs therapy. AASLD Abstracts. Hepatology. 2018;68(1).

51. Wedemeyer $H$, Hui AJ, Sukeepaisarnjaroen W, Tangkijvanich P, Guillén G, Gineste P, et al. Therapeutic vaccination of chronic hepatitis $B$ patients with ABX203 (NASVAC) to prevent relapse after stopping NAs: contrasting timing rebound between tenofovir and entecavir. J Hepatol. 2017 Dec; 66:S101.

\section{THE AUTHORS}

Eduardo Pentón-Arias (Corresponding author: eduardo.penton@cigb.edu.cu) physician specializing in clinical biochemistry with a doctorate in biological sciences. Senior researcher, Latin American School of Medicine (ELAM) and Genetic Engineering and Biotechnology Center (CIGB). Hepatitis B Group, Vaccine Department, Biomedical Research Division, CIGB, Havana, Cuba. https://orcid.org/0000-0002-0574-7942

Julio César Aguilar-Rubido, biologist, Hepatitis B Group, Vaccine Department, Biomedical Research Division, CIGB, Havana, Cuba. https://orcid.org/0000-0003-0166-4784

Submitted: January 14, 2020

Approved for publication: January 9, 2021

Disclosures: Eduardo Pentón-Arias belongs to the group that developed the Cuban recombinant hepatitis vaccine Heberbiovac $H B$ at CIGB and Julio César Aguilar-Rubido is a researcher at CIGB. Both Heberbiovac HB and HeberNasvac are produced by CIGB. 